\title{
PENGARUH VARIASI PARAMETER PENGELASAN TERHADAP KUALITAS HASIL PENGELASAN
}

\author{
Sonja Treisje A. Lekatompessy \\ e-mail: sonja_lekatompessy@yahoo.com \\ Fakultas Teknik Universitas Pattimura, Ambon
}

\begin{abstract}
ABSTRAK
Salah satu hal penting yang mempengaruhi kualitas hasil pengelasan adalah besarnya arus las. Penelitian ini bertujuan untuk mengetahui seberapa besar pengaruh arus pengelasan terhadap kualitas hasil pengelasan melalui pengujian tarik dan pengamatan secara mikroskopik. Material yang digunakan dalam penelitian adalah baja ST-37 Benda uji dengan cara memotong pelat strip baja tersebut dan dibuat kampuh $\mathrm{V}$ untuk pengelasan, dan dibuat spesimen uji tarik sesuai dengan standar ASTM E8 dan disesuaikan dengan kapasitas mesin uji tarik yang digunakan. Proses pengelasan dilakukan menggunakan mesin las SMAW DC dengan elektroda E6010. Variasi arus pengelasan 70 Ampere, 80 Ampere dan 90 Ampere. Dari hasil penelitian diharapkan bahwa semakin besar arus pengelasan semakin besar pula kekuatan tarik.
\end{abstract}

Kata kunci : SMAW, elektroda E6010, Kekuatan Tarik

\section{PENDAHULUAN}

Pengelasan merupakan salah satu proses penyambungan logam. Pada proses pengelasan banyak faktor yang mempengaruhi kualitas dari hasil pengelasan diantaranya: mesin las yang digunakan, bahan yang digunakan, prosedur pengelasan, cara pengelasan, arus pengelasan dan juru las. Kualitas dari hasil pengelasan dapat diketahui dengan cara memberikan gaya atau beban pada hasil lasan tersebut. Gaya atau beban yang diberikan dapat berupa pengujian tarik dan ketangguhan pada bahan tersebut.

Las SMAW adalah suatu proses pengelasan busur listrik yang mana penggabungan atau perpaduan logam yang dihasilkan oleh panas dari busur listrik yang dikeluarkan diantara ujung elektroda terbungkus dan permukaan logam dasar yang dilas dengan menggunakan arus listrik sebagai sumber tenaga. Jenis arus listrik yang digunakan ada 2 yaitu arus searah (DC) dan arus bolak-balik (AC). Pengelasan dengan arus searah pemasangan kabel pada mesin las ada 2 macam yaitu polaritas lurus (DC-) dan polaritas terbalik (DC+). Pada polaritas terbalik $(\mathrm{DC}+)$ panas yang diberikan mesin las untuk memanaskan benda dan untuk memanaskan elektroda. Logam induk dalam pengelasan ini mengalami pencairan akibat pemanasan dari busur listrik yang timbul antara ujung elektroda dan permukaan benda kerja. Busur listrik dibangkitkan dari suatu mesin las. Elektroda yang digunakan berupa kawat yang dibungkus pelindung berupa fluks. Elektroda ini selama pengelasan akan mengalami pencairan bersama dengan logam induk dan membeku bersama menjadi bagian kampuh las.Proses pemindahan logam elektroda terjadi pada saat ujung elektroda mencair dan membentuk butirbutir yang terbawa arus busur listrik yang terjadi.
Bila digunakan arus listrik besar maka butiran logam cair yang terbawa menjadi halus dan sebaliknya bila arus kecil maka butirannya menjadi besar.

Pengelasan dengan menggunakan las SMAW DC polaritas terbalik besarnya arus bermacammacam sesuai dengan jenis elektroda. Penyetelan arus pengelasan akan berpengaruh pada panas yang ditimbulkan dalam pencairan logam dan penetrasi logam cairan tersebut. Arus yang tinggi akan mengakibatkan panas yang tinggi, penembusan atau penetrasi yang dalam dan kecepatan pencairan logam yang tinggi. Arus yang kecil menghasilkan panas yang rendah dan tidak cukup untuk melelehkan elektroda dan bahan logam. Penembusan, panas dan kecepatan pencairan logam akan berpengaruh pada kualitas baja maupun hasil pengelasan.

\section{KAJIAN TEORI DAN METODE}

Las busur listrik adalah proses penyambungan logam dengan pemanfaatan tenaga listrik sebagai sumber panasnya. Menurut (Arifin dalam Suparman, 2006) las busur listrik merupakan salah satu jenis las listrik dimana sumber pemanasan atau pelumeran bahan yang disambung atau dilas berasal dari busur nyala listrik. Logam induk dalam pengelasan ini mengalami pencairan akibat pemanasan dari busur listrik yang timbul antara ujung elektroda dan permukaan benda kerja. Busur listrik dibangkitkan dari suatu mesin las. Elektroda yang digunakan berupa kawat yang dibungkus pelindung berupa fluks. Elektroda ini selama pengelasan akan mengalami pencairan bersama dengan logam induk dan membeku bersama menjadi bagian kampuh las (Santoso, 2006).

Proses pemindahan logam elektroda terjadi pada saat ujung elektroda mencair dan membentuk butir- 
butir yang terbawa arus busur listrik yang terjadi. Bila digunakan arus listrik besar maka butiran logam cair yang terbawa menjadi halus dan sebaliknya bila arus kecil maka butirannya menjadi besar. Pola pemindahan logam cair sangat mempengaruhi sifat mampu las dari logam. Logam mempunyai sifat mampu las yang tinggi bila pemindahan terjadi dengan butiran yang halus. Pola pemindahan cairan dipengaruhi oleh besar kecilnya arus dan komposisi dari bahan fluks yang digunakan. Bahan fluks yang digunakan untuk membungkus elektroda selama pengelasan mencair dan membentuk terak yang menutupi logam cair yang terkumpul di tempat sambungan dan bekerja sebagai penghalang oksidasi.

Rancangan dan prosedur penelitian yang dilakukan antara lain :

spesifikasi alat dan bahan yang digunakan dalam eksperimen ini adalah sebagai berikut:

> Bahan yang digunakan baja paduan rendah ST37 berupa pelat strip dengan Ketebalan plat 5 $\mathrm{mm}$ dan lebar $750 \mathrm{~mm}$. Elektroda yang digunakan adalah jenis E6010 dengan diameter $2,6 \mathrm{~mm}$.

> Posisi pengelasan dengan menggunakan posisi bawah tangan atau mendatar, dengan posisi elektroda dengan sudut $80^{\circ}$ terhadap benda kerja ke arah jalan elektroda.

$>$ Variasi Arus pengelasan yang digunakan adalah 70 Ampere, 80 Ampere, dan 90 Ampere.

$>$ Kampuh yang digunakan jenis kampuh $\mathrm{V}$ terbuka dengan sudut $70^{\circ}$.

$>$ Bentuk spesimen uji berdasarkan standard ASTM E8 untuk uji tarik.

\section{Bentuk Spesimen Uji Tarik}

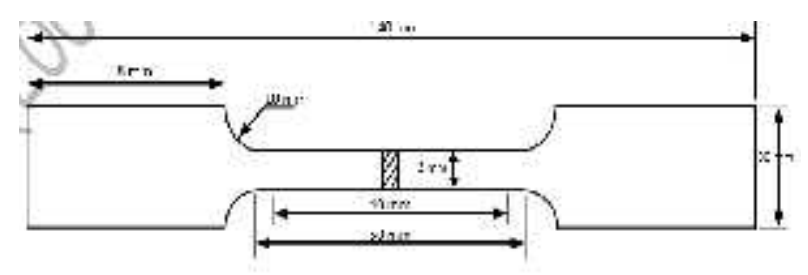

Gambar 1. Spesimen Uji Tarik

Setelah dilakukan pengelasan, pembuatan ukuran spesimen uji dan permukaan spesimen uji dibuat lebih halus untuk pengamatan metalografi. Kemudian dilakukan pengujian tarik dengan menggunakan Universal Machine Test. Setelah data diperoleh selanjutnya adalah hasil pengujian dimasukkan ke dalam persamaan-persamaan yang ada sehingga diperoleh data yang bersifat kuantitatif, yaitu data yang berupa angka-angka. Teknik analisa data pengaruh arus pengelasan terhadap kekuatan tarik baja karbon rendah las SMAW dengan elektroda E6010 berupa perbandingan prosentase dan rata-rata antara data-data dari variasi arus pengelasan.

\section{HASIL DAN PEMBAHASAN}

Tabel 1. Perbandingan dari hasil pengujian tarik pada setiap kondisi perlakuan kelompok benda uji.

$\begin{array}{llccc}\text { No } & \begin{array}{c}\text { Perlakuan } \\ \text { Benda Uji }\end{array} & \begin{array}{c}\text { Tegangan } \\ \text { Tarik }(\sigma) \\ \left(\mathrm{kg} / \mathrm{mm}^{2}\right)\end{array} & \begin{array}{c}\text { Regangan } \\ (\varepsilon) \\ (\%)\end{array} & \begin{array}{c}\text { Reduksi } \\ \text { Penampang } \\ (\mathrm{q})\end{array} \\ & & & & (\%) \\ 1 & \text { Material Uji } & 52.33 & 17.23 & 60.50 \\ 2 & \text { Arus 70 A } & 53.16 & 16.63 & 53.46 \\ 3 & \text { Arus 80 A } & 54.20 & 15.40 & 55.18 \\ 4 & \text { Arus 90 A } & 54.94 & 17.30 & 53.71\end{array}$

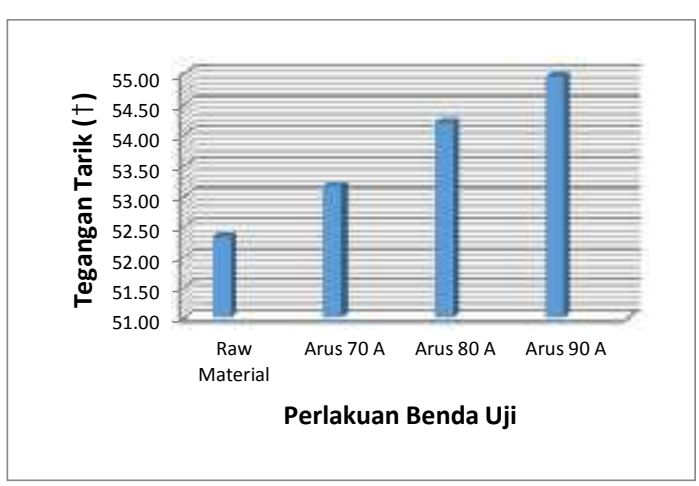

Gambar 2. Diagram perbandingan tegangan tarik $(\sigma)$ dari hasil pengujian tarik pada setiap kondisi perlakuan kelompok benda uji

Dalam table 1 dan gambar 1 terlihat bahwa nilai kekuatan tarik untuk kelompok specimen dengan perlakuan pengelasan, seluruhnya mengalami peningkatan kekuatan tarik terhadap kelompok spesimen raw material. Dimana untuk kelompok specimen dengan perlakuan pengelasan terlihat bahwa semakin besar arus pengelasan yang diberikan (70 Ampere, 80 Ampere dan 90 Ampere) akan semakin besar pula nilai kekuatan tarik pada baja yang terpengaruh arus pengelasan tersebut.

\section{KESIMPULAN}

Nilai tegangan tarik $(\sigma)$ untuk kelompok spesimen dengan perlakuan pengelasan seluruhnya mengalami kenaikan dibandingkan dengan kelompok raw material, dimana untuk perlakuan pengelasan dengan arus yang lebih besar memiliki tegangan tarik yang lebih besar dari kelompok perlakuan pengelasan dengan arus yang lebih kecil. Hal ini sama dengan rumusan hipotesis pada bab II yang menyatakan bahwa: "Ada pengaruh variasi arus pengelasan terhadap kualitas baja paduan rendah ST-37 yaitu semakin besar arus akan membuat kekuatan tarik baja semakin besar pula". 
Proses pengelasan sangat mempengaruhi sifat fisis dan mekanis dari baja ST-37, di mana akan terjadi perubahan struktur kristal akibat masukanpanas yang tinggi pada saat pengelasan dan mempengaruhi kekuatan tarik baja tersebut.

\section{SARAN}

> Perlu dilakukan penelitian lebih lanjut dengan menambah variasi arus pengelasan sehingga didapat hasil yang lebih optimal. Dan perlu dilakukan penelitian lebih lanjut dengan menambah variasi pengujian yaitu pengujian impact dan pengujian kekerasan.

- Perlu pengadaan atau penambahan kapasitas untuk mesin uji universal yang lebih besar.

\section{DAFTAR PUSTAKA}

Santoso, J., 2006, Pengaruh Arus Pengelasan Terhadap Kekuatan Tarik dan Ketangguhan Las SMAW Dengan Elektroda E7018, Skripsi tidak diterbitkan. Semarang: TM FATEK Universitas Negeri Semarang
Suparman, 2006, Pengaruh Suhu Annealing pada Post Weld Heat Treatment Pengelasan Baja Bohler Grade K-945 EMS 45 Terhadap Sifat Fisis dan Mekanis, Skripsi tidak diterbitkan, Semarang: TM FATEK Universitas Negeri Semarang

Widharto, 2008, Petunjuk Kerja Las. PT.Pradnya Paramita. Jakarta.

Yos, M. Ikbal, 2004, Basic of welding modulefor welding inspekto Competency Maritime \& OffShore Engineering Vocational School \& Training Specialist. Ilmu Kelautan Bina Maritim, Batam

Yuwono, A. Herman, 2009, Buku Panduan Praktikum Karakterisasi Material 1 Pengujian Merusak (Destructive Testing), Departemen Metalurgi dan Material Fakultas Teknik Universitas Indonesia, Jakarta 